\title{
Genetic Progress Through Hybridization of Induced and Natural Tetraploids in Crested Wheatgrass
}

\author{
K.H. ASAY, D.R. DEWEY, F.B. GOMM, W.H. HORTON, AND K.B. JENSEN
}

\section{Abstract}

Because of restrictions imposed by crossing barriers, crested wheatgrass breeders have usually limited themselves to selection and hybridization within ploidy levels i.e., diploid $(2 n=14)$, tetraploid $(2 n=28)$, or hexaploid $(2 n=42)$ populations. Several procedures have now been devised and evaluated to transfer genetic traits among ploidy levels, and interploidy breeding appears to be a feasible approach in the crested wheatgrass complex. Plant scientists with the USDA-ARS at Utah State University have developed a superior breeding population by hybridizing induced tetraploid Agropyron cristatum (L.) Gaertn. with natural tetraploid $A$. desertorum (Fisch. ex Link) Schult. The cultivar 'Hycrest' was released from this germplasm base in 1984. Chromosome number of the Hycrest breeding population ranged from $2 n=28$ to 32 and averaged 30. Chromosome pairing relationships were similar to those observed in natural tetraploids and the cultivar was as fertile as the parental species. Hycrest produced significantly more seeds per spike than 'Nordan,' and ample genetic variability for seed set existed in the population to make additional improvement through selection. Hycrest produced significantly $(P<0.05)$ more forage than Nordan and Fairway in 9 of 12 comparisons at 5 semiarid range sites. The superiority of the cultivar was most noteworthy during and immediately after stand establishment on harsh sites. The need to expand the genetic base of the present population with selected parental materials is recognized.

Since its successful introduction from Eurasia in 1906 (Dillman 1946), crested wheatgrass has had more impact on revegetation of western rangelands than any other grass. This widely adapted cool-season perennial grass is actually a complex of diploid $(2 n=2 x=14)$, tetraploid $(2 n=4 x=28)$, and hexaploid $(2 n=6 x=42)$ taxa. The diploid form is represented in North America by fairway [Agropyron cristatum (L.) Gaertn.]. The most common tetraploids are standard [ $A$. desertorum (Fisch. ex Link) Schult.] and siberian [A. fragile (Roth) Candargy]. The tetraploids are most prevalent on rangelands in the U.S. and the diploids are the most important form in Canada (Asay and Knowles 1985). New sources of diploid germplasm have recently been reported (Dewey and Asay 1982, Dewey and Hsiao 1984) and may be instrumental in future breeding efforts. Although hexaploid ecotypes have been introduced in North America and eventually may be a factor in rangeland improvement, observations to date indicate that they have limited merit in a plant breeding program.

Based on chromosome pairing relationships in interploidy hybrids, Dewey (1974) concluded that the same basic genome, modified by structural rearrangements, occurred at the three ploidy levels. He advised crested wheatgrass breeders to treat the species in the complex as a single gene pool. Although interploidy crosses are often difficult to make and sterility problems are encountered in hybrid progenies, all possible crosses have been made among the diploid $(2 x)$, tetraploid $(4 x)$, and hexaploid $(6 x)$ levels and several schemes have been devised and tested to effect interploidy genetic transfer (Asay and Dewey 1983).

The most progress from interploidy breeding to date has been achieved at the $4 x$ level. Hybridization schemes involving $6 x-2 x$, $6 x-4 x, 4 x-2 x$, and hybrids between colchicine-induced tetraploids $(\mathrm{C} 4 \mathrm{x})$ and natural tetraploids (N4x) have shown potential for

\footnotetext{
Authors are research geneticists, range scientist retired, support scientist, and graduate assistant, USDA-ARS, Crops Research Laboratory, Utah State University, UMC-63, Logan, Utah 84322

Manuscript accepted 8 August 1985.
}

expanding the genetic resources of $4 x$ breeding populations (Asay and Dewey 1979; Dewey 1969, 1971, 1974; Dewey and Pendse 1968; Knowles 1955). Plant materials from C4x-N4x crosses have been particularly promising. Tai and Dewey (1966) found that C4x tetraploids were relatively fertile and crossed readily with natural tetraploids. Although the fertility of the $F_{1}$ hybrid was variable, average seed set compared favorably with that of the parental lines. Dewey and Pendse's (1968) data also indicated that selection for improved fertility would be effective. Many of the hybrid clones were substantially more vigorous than the parental species.

In 1974, progenies from $295 \mathrm{~F}_{3}$ clones of the $\mathrm{C} 4 \mathrm{x}-\mathrm{N} 4 \mathrm{x}$ hybrid were entered in the USDA-ARS grass breeding at Logan, Utah. On the basis of evaluation in an 8,000-plant source nursery and subsequent progeny tests, 18 clonal lines were selected and isolated in a crossing block to form the parentage of a synthetic strain. Selection criteria included vigor of seedlings and mature plants, yield of forage and seed, leafiness, resistance to plant pests, and response to environmental stress. The experimental strain, subsequently released as the cultivar 'Hycrest' (Asay et al. 1985), is the first interspecific hybrid of crested wheatgrass to be released.

The objectives of these studies were to determine the range in chromosome number, meiotic regularity, and fertility of the $\mathrm{C4x}-$ $\mathrm{N} 4 \mathrm{x}$ hybrid and to compare the agronomic merit of the hybrid with commercially available cultivars of crested wheatgrass. The data will provide a basis to evaluate the potential of combining the genetic resources of diploid and tetraploid crested wheatgrass through interploidy hybridization.

\section{Materials and Methods}

Plant materials consisted of the $\mathrm{F}_{5}$ generation of the $\mathrm{C} 4 \mathrm{x}-\mathrm{N} 4 \mathrm{x}$ crested wheatgrass hybrid represented by the Syn-1 generation of the cultivar Hycrest. The research was conducted in 2 phases: (1) cytological studies of meiotic regularity and fertility of the hybrid, and (2) evaluation of the hybrid's seedling vigor, forage yield, and seed yield on semiarid range sites. The commercially available cultivars 'Nordan' and 'Fairway' were included in the second phase for comparative purposes.

One-hundred clones, randomly selected from a breeding nursery consisting of 3,000 Syn-1 $\left(\mathrm{F}_{5}\right)$ plants, were included in the studies of meiotic regularity and fertility. Spikes for cytological analyses were collected from 20 clones, fixed in Carnoy's $(6: 3: 1)$ solution, and stored under refrigeration in $70 \%$ cthanol. Squash preparations of pollen mother cells were made with acetocarmine as the strain. Chromosome pairing relationships, number of lagging chromosomes, and frequency of micronuclei were determined at metaphase-1, anaphase-1, and the quartet stages of meiosis, respectively. Pollen viability was estimated by staining pollen grains with aqueous $I_{2}-K I$ solution. At seed maturity, 10 open pollinated (OP) spikes were collected from each of the 100 plants for determination of seed set (seeds/spike).

Stand establishment data and forage yield were obtained at 5 locations (A - E) in Utah, Idaho, and Montana (Table 1). Studies were arranged as randomized complete blocks at all locations with 4 replicates at locations $A$ and $B$ and 2 replicates at $C, D$, and $E$. Plot size was 1.5 by $40 \mathrm{~m}$ at Location $A, 3$ by $15 \mathrm{~m}$ at $B, 3$ by $30 \mathrm{~m}$ at $\mathrm{C}$ and $\mathrm{E}$, and 1.5 by $30 \mathrm{~m}$ at $\mathrm{D}$. Drilled rows within plots were spaced $0.3 \mathrm{~m}$ apart at all locations. Forage yields were determined from $1-\mathrm{m}^{2}$ samples randomly chosen in each plot. Two to 3 samples were taken per plot at locations with 2 replicates. Forage samples 
Table 1. Description of study sites from which stand establishment and forage yield were determined.

\begin{tabular}{|c|c|c|c|c|c|}
\hline Site & Location & $\begin{array}{l}\text { Avg. Annual } \\
\text { Precip. (cm) }\end{array}$ & Soil Series & Planting Date & Harvest Dates \\
\hline $\mathbf{A}$ & $\begin{array}{l}\text { Decker Montana } \\
\text { Coal Surface Mine }\end{array}$ & 31.8 & + & 10 Oct. 83 & 2 Aug. 84 \\
\hline B & $\begin{array}{l}\text { Utah State Univ. } \\
\text { Blue Creek Exp. } \\
\text { Stn. NW Utah }\end{array}$ & 36.6 & $\begin{array}{l}\text { Kearns } \\
\text { (silt loam) }\end{array}$ & 24 April 84 & 9 July 84 \\
\hline $\mathrm{C}$ & $\begin{array}{l}\text { Univ. of Idaho } \\
\text { Sharp Grazing Trials } \\
\text { Sublette, Idaho }\end{array}$ & 32.4 & $\begin{array}{l}\text { Sublette (fine silty } \\
\text { mixed) }\end{array}$ & 14 April 83 & 25 June 84 \\
\hline D & $\begin{array}{l}\text { Lakeside, Utah } \\
\text { Near Bonneville Salt Flats, } \\
\text { Flats, NW Utah }\end{array}$ & 15.4 & $\begin{array}{l}\text { Escalante (fine sandy } \\
\text { loam) }\end{array}$ & 7 April 81 & $\begin{array}{l}14 \text { July } 83 \\
28 \text { June } 84\end{array}$ \\
\hline $\mathbf{E}$ & $\begin{array}{l}\text { Thiokol, Wasatch } \\
\text { Div., NW Utah }\end{array}$ & 35.8 & Sanpete (silt loam) & 26 April 82 & $\begin{array}{r}8 \text { June } 83 \\
13 \text { June } 84\end{array}$ \\
\hline
\end{tabular}

+Approximately $0.45 \mathrm{~m}$ chugter loam topsoil (Tongue River member of Fort Union Formation, embedded with sandstone and shale spoil material) transported to coal surface mine overburden.

were oven dried for $48 \mathrm{hr}$ at $40^{\circ} \mathrm{C}$ and data were reported as $\mathrm{kg}$ of dry matter per ha. Trials were established at 2 sites, approximately $5 \mathrm{~km}$ apart, at location $\mathrm{D}$. Seed yield was determined from adjacent 0.5-ha stands of Hycrest and Nordan at Location C. Seed was harvested from 5 randomly selected $3 \times 0.3-\mathrm{m}$ rows of each cultivar during the year after stand establishment. Stand density and soil type were uniform for the 2 cultivars. Analyses of variance were computed on all forage yield and seed yield data.

\section{Results and Discussion}

The $2 n$ chromosome number of the 20 plants included in the cytological studies consisted of 9 with 28,6 with 30 , and 5 with 32 (Table 2). Chromosome numbers in excess of $2 n=28$ are not expected. Dewey and Pendse (1968) also found extra chromosomes in $A$. desertorum, some of which may have been $B-$ chromosomes. These B-chromosomes may have accounted for the rather high number of univalents observed in the aneuploid plants. Mean univalents per cell were 1.54 and 1.04 in plants with 30 and 32 chromosomes, respectively. The euploid $(2 n=28)$ plants averaged 0.55 univalents per cell. Other cytological data are consistent with what would be expected in autotetraploid crested wheatgrass. Frequency of bivalents ranged from 4 to 15 and averaged 9.85 per cell. From 0 to 4 trivalents or quadrivalents were found per cell with an average 0.63 and 1.66 , respectively. Configurations involving 7 and 8 chromosomes along with observations of 0.10 laggards per cell and 0.16 micronuclei per quartet support the premise that structural heterozygosity exists between the $A$. desertorum and $A$. cristatum genomes.

The relatively stable meiotic patterns are reflected in the fertility data. Hycrest produced significantly $(P<0.01)$ more seeds per spike than Nordan under range conditions (Table 3). Moreover,

Table 3. Seed fertility (seed-set), seed weight, and seed yield of Hycrest and Nordan crested wheatgrass.

\begin{tabular}{|c|c|c|c|c|}
\hline \multirow[t]{2}{*}{ Cultivar } & \multicolumn{2}{|c|}{ Seed-set } & \multirow{2}{*}{$\frac{\text { Seed Wt }}{g / 100 \text { seeds }}$} & \multirow{2}{*}{$\frac{\text { Seed Yield }}{\mathrm{kg} / \mathrm{ha}}$} \\
\hline & Seeds/spike & g/spike & & \\
\hline $\begin{array}{l}\text { Hycrest } \\
\text { Nordan } \\
\text { LSD }(0.05)\end{array}$ & $\begin{array}{r}27.9 \\
13.6 \\
6.4\end{array}$ & $\begin{array}{l}0.07 \\
0.03 \\
0.02\end{array}$ & $\begin{array}{l}0.27 \\
0.24 \\
\text { NS }\end{array}$ & $\begin{array}{l}360 \\
260 \\
\text { NS }\end{array}$ \\
\hline
\end{tabular}

All data collected from range site near Location $C$.

excellent opportunities remain in the population for additional improvement. The 98 plants studied in a breeding nursery produced from 0 to 110.6 seeds per spike with an average of 27.2 and a standard error of 24 . Sixteen of the 98 plants produced more than $\mathbf{5 0}$ seeds per spike. Stainable pollen of the Hycrest clones sampled averaged $76 \%$ and ranged from 62 to $85 \%$. Although more data are needed to document the seed yield potential of Hycrest, limited observations to date (Table 3 ) suggest that the new cultivar compares favorably with Nordan. During the year after seeding on a range site, seed production for Hycrest was $362 \mathrm{~kg} /$ ha compared to $258 \mathrm{~kg} /$ ha for Nordan.

The most noteworthy attributes of Hycrest are its vigor and productivity during and immediately after stand establishment (Table 4). Hycrest produced significantly $(P<0.05$ and 0.01$)$ more forage than Nordan and Fairway in 9 of the 12 comparisons made at the 5 study sites. The advantage was greatest during the early phases of stand establishment and under environmental stress. For example, at Decker, Mont., where moisture conditions were near optimum during the year after seeding, excellent stands were obtained for all crested wheatgrass entries. Although Hycrest pro-

Table 2. Meiotic regularity in Hycrest Syn-1 crested wheatgrass.

\begin{tabular}{|c|c|c|c|c|c|c|c|c|c|c|c|c|c|}
\hline \multirow[b]{3}{*}{ 2n chrom } & \multirow{3}{*}{$\begin{array}{c}\text { No. } \\
\text { plants }\end{array}$} & & \multicolumn{7}{|c|}{ Metaphase I } & \multicolumn{2}{|c|}{ Anaphase I } & \multicolumn{2}{|c|}{ Quartets } \\
\hline & & & \multirow{2}{*}{$\begin{array}{l}\text { No. } \\
\text { cells }\end{array}$} & \multicolumn{5}{|c|}{ Chrom. Assoc. (No./cell) } & \multirow{2}{*}{$\underset{(\%)}{\operatorname{Ring} I I}$} & \multirow{2}{*}{$\begin{array}{l}\text { No. } \\
\text { cells }\end{array}$} & \multirow{2}{*}{$\begin{array}{c}\text { Laggards/ } \\
\text { cell }\end{array}$} & \multirow{2}{*}{$\begin{array}{c}\text { No. } \\
\text { quartets }\end{array}$} & \multirow{2}{*}{$\begin{array}{c}\text { Micronuclei/ } \\
\text { quartet }\end{array}$} \\
\hline & & & & I & II & III & IV & $>I V$ & & & & & \\
\hline 28 & 9 & $\begin{array}{l}\text { Range } \\
\text { Mean }\end{array}$ & 71 & $\begin{array}{l}0-3 \\
0.55\end{array}$ & $\begin{array}{l}4-14 \\
9.63\end{array}$ & $\begin{array}{l}0-4 \\
0.65\end{array}$ & $\begin{array}{l}0-4 \\
1.44\end{array}$ & $\begin{array}{l}0-1 \\
0.11\end{array}$ & 61 & 330 & $\begin{array}{l}0-2 \\
0.07\end{array}$ & 345 & $\begin{array}{l}0-4 \\
0.17\end{array}$ \\
\hline 30 & 6 & $\begin{array}{l}\text { Range } \\
\text { Mean }\end{array}$ & 59 & $\begin{array}{l}0-7 \\
1.54\end{array}$ & $\begin{array}{l}4-15 \\
9.31\end{array}$ & $\begin{array}{l}0-4 \\
0.78\end{array}$ & $\begin{array}{l}0-4 \\
1.78\end{array}$ & $\begin{array}{l}0-1 \\
0.07\end{array}$ & 69 & 191 & $\begin{array}{l}0-2 \\
0.16\end{array}$ & 250 & $\begin{array}{l}0-3 \\
0.23\end{array}$ \\
\hline 32 & 5 & $\begin{array}{l}\text { Range } \\
\text { Mean }\end{array}$ & 25 & $\begin{array}{l}0-6 \\
1.04\end{array}$ & $\begin{array}{r}5-14 \\
10.88\end{array}$ & $\begin{array}{l}0-2 \\
0.40\end{array}$ & $\begin{array}{l}0-4 \\
1.92\end{array}$ & $\begin{array}{l}0-1 \\
0.08\end{array}$ & 70 & 202 & $\begin{array}{l}0-2 \\
0.08\end{array}$ & 203 & $\begin{array}{l}0-2 \\
0.06\end{array}$ \\
\hline 28-32 & 20 & $\begin{array}{l}\text { Range } \\
\text { Mean }\end{array}$ & 155 & $\begin{array}{l}0-7 \\
0.97\end{array}$ & $\begin{array}{l}4-15 \\
9.85\end{array}$ & $\begin{array}{l}0-4 \\
0.63\end{array}$ & $\begin{array}{l}0-4 \\
1.66\end{array}$ & $\begin{array}{l}0-1 \\
0.09\end{array}$ & 67 & 723 & $\begin{array}{l}0-2 \\
0.10\end{array}$ & 798 & $\begin{array}{l}0-4 \\
0.16\end{array}$ \\
\hline
\end{tabular}


Table 4. Forage yield of three crested whentgrass cultivars on five range sites during stand establishment (Yr-1) and subsequent seasons (Yr-2 and Yr-3).

\begin{tabular}{|c|c|c|c|c|c|c|c|}
\hline \multirow[b]{3}{*}{ Cultivar } & \multicolumn{7}{|c|}{ Location } \\
\hline & \multirow{2}{*}{$\frac{A}{Y r-1}$} & \multirow{2}{*}{$\frac{B}{Y r-1}$} & \multirow{2}{*}{$\frac{C}{Y r-2}$} & \multicolumn{2}{|c|}{ D } & \multicolumn{2}{|c|}{ E } \\
\hline & & & & Yr-2 & Yr-3 & $\mathrm{Yr}-2$ & Yr-3 \\
\hline & & & & $-\mathrm{kg} / \mathrm{hr}$ & & & \\
\hline Hycrest & 4090 & 1340 & 2510 & 2610 & 2050 & 3950 & 2670 \\
\hline Nordan & 3790 & 480 & 1740 & 1550 & 1500 & 2440 & 1950 \\
\hline Fairway & 3630 & 630 & & 960 & 1410 & 3180 & - \\
\hline LSD (0.05) & 550 & 120 & 500 & 390 & 250 & 830 & 470 \\
\hline
\end{tabular}

duced more forage than the other 2 cultivars, the differences were not significant. At the other locations, where substantial drought stress was encountered, the superiority of Hycrest was much more evident.

The hybrid was most impressive at Lakeside, Utah, near the Bonneville salt flats (Location D). In addition to extremely harsh environmental conditions, the area was infested with halogeton [Halogeton glomeratus (Bieb.) C.A. Mey.] and cheatgrass (Bromus tectorum $\mathrm{L}$ ). Native vegetation was shadscale [Atriplex confertifolia (Torr. \& Frem.) S. Wats.] bud sage (Artemesia spinescens D.C. Eaton), and squirreltail [Elymus elymoides (Raf.) Sweezy = Sitanion hystrix (Nutt.) J.G. Smith]. Excellent stands of the cultivar were obtained with no herbicide application; and by the second year, both weed species were essentially eliminated. Forage yields averaged over 2 sites at Location D during the first year after stand establishment were $2,610,1,550$, and $960 \mathrm{~kg} / \mathrm{ha}$, for Hycrest, Nordan, and Fairway, respectively. Corresponding values for the next year were $2,050,1,500$ and $1,410 \mathrm{~kg} / \mathrm{ha}$.

Seed weight has been positively correlated with seedling vigor in forage grasses and some of the vigor edge of Hycrest during stand establishment may be related to its larger seeds. Limited data available to date show that Hycrest tends to have heavier seeds than commercial seedlots of Fairway and to a lesser extent, Nordan. The difference in seed weight of Hycrest and Nordan collected from a range site was not significant.

The initial results from interploidy breeding in crested wheatgrass are encouraging, but the need for further research is evident. The present population stems from a relatively narrow genetic base. New breeding populations need to be generated from crosses and backcrosses involving selected $A$. cristatum and $A$. desertorum clones. Comparatively little selection has been done to date to improve nutritive value of the interploidy plant materials. Preliminary data (Park et al. 1983) indicate that genetic variability is present in hybrid populations for nitrogenous and fibrous fractions of the forage. The development of near-infrared reflectance technology should permit the assay of larger populations than presently possible. The genetic mechanisms responsible for the superiority of Hycrest over its parental species have not been explained. The relative importance of additive and nonadditive genetic effects need to be determined. Any changes in vigor and other important characteristics in advanced generations are of some concern. Results obtained to date indicate that the hybrid population is stable and in fact has been improved through selection during the 4 generations after the initial cross.

\section{References}

Asay, K.H., and D.R. Dewey. 1979. Bridging ploidy differences in crested wheatgrass with hexaploid $X$ diploid hybrids. Crop Sci. 19:519-523.

Asay, K.H., and D.R. Dewey. 1983. Pooling the genetic resources of the crested wheatgrass species-complex. J.A. Smith and V.W. Hays (eds.). Proc. Int. Grassl. Cong., Lexington, Ky. 15-24 June 1981. 14:124-127.

Asay, K.H., D.R. Dewey. F.B. Gomm, D.A. Johnson, and J.R. Carlson. 1985.

Registration of Hycrest crested wheatgrass. Crop Sci. 25:368-369.

Asay, K.H., and R.P. Knowles. 1985. Wheatgrasses. p. 590-606. In: R.F. Barnes, D.S. Metcalfe, and M.E. Heath (ed.) Forages: The Science of Grassland Agriculture. Ed. 4. The Iowa State Univ. Press, Ames.

Dewey, D.R. 1969. Hybrids between tetraploid and hexaploid crested wheatgrass. Crop Sci. 9:787-791.

Dewey, D.R. 1971. Reproduction in crested wheatgrass triploids. Crop Sci. 11:575-580.

Dewey, D.R. 1974. Reproduction in crested pentaploids. Crop Sci. 14:867-872.

Dewey, D.R., and C.I. Hsiao. 1984. The source of variation in tetraploid crested wheatgrass. Agron Abstr. 1984:64.

Dewey, D.R., and K.H. Asay. 1982. Cytogenetic and taxonomic relationships among three diploid crested wheatgrass. Crop Sci. 22:645-650.

Dewey, D.R., and P.C. Pendse. 1968. Hybrids between Agropyron desertorum and induced-tetraploid Agropyron cristatum. Crop Sci. 8:607-611.

Dillman, A.C. 1946. The beginnings of crested wheatgrass in North America. J. Amer. Soc. Agron. 38:237-250.

Knowles, R.P. 1955. A study of variability in crested wheatgrass. Can. J. Bot. 33:534-546.

Park, Y.W., M.J. Anderson, K.H. Asay, and A.W. Mahoney. 1983. Predicting soluble nitrogen and fibrous fractions in crested wheatgrass with near-infrared-reflectance spectroscopy. J. Range. Manage. 36:529-533.

Tai, W., and D.R. Dewey. 1966. Morphology, cytology, and fertility of diploid and colchicine-induced tetraploid crested wheatgrass. Crop Sci. 6:223-226. 